\title{
Causes and psychological impact of gynecomastia in boys and adolescents
}

\author{
Zdravka P. Todorova ${ }^{\circledR 1}$, Elissaveta M. Stefanova ${ }^{\circledR 1}$, Ivilin P. Todorov ${ }^{\circledR 2}$ \\ ${ }^{1}$ Department of Endocrinology, Specialized Hospital for Active Treatment of Paediatric Diseases, Faculty of Medicine, \\ Medical University - Sofia, Sofia, Bulgaria \\ ${ }^{2}$ Department of Cardiothoracic Surgery, Acibadem City Clinic Tokuda Hospital, Sofia, Bulgaria
}

Key words: prepubertal gynecomastia; adolescent gynecomastia; pathologic gynecomastia; psychological influence of gynecomastia

\section{Introduction}

Gynecomastia (GM) is a unilateral or bilateral benign proliferation of the glandular tissue of breast in males [1]. During three periods of the individual life GM is considered a physiological phenomenon - in the neonatal, during adolescence and in senile men. GM itself is not a disease, but rather a condition or symptom of an underlying disease that has led to an altered balance, at the level of breast tissue, between the level and effect of estrogens and androgens due to an absolute increase in estrogen levels, absolute or relative decrease in androgen levels, altered bioavailability, disorders of androgen receptors or hypersensitivity of the glandular tissue [2, 3]. Overweight and obesity among children and adolescents play an important role in the development of GM [4]. The causes of pathologic GM and their incidence in adult men are widely known. However for children and adolescents, there is almost no accurate data on the prevalence of different causes of pathological GM. The aim of the study is to investigate the causes of prepubertal and pathologic pubertal GM, its association with obesity among patients admitted to endocrinology clinic. In addition analysis of its psychological impact was performed.

\section{Material and methods}

Medical records of boys and adolescents referred to tertiary department of endocrinology because of GM or diagnosed with GM during clinical evaluation between 2009 and 2018 were selected $(n=157)$ to be included in the presented retrospective cross-sectional study. GM was assessed by means of palpation and in suspicious for pseudo gynecomastia cases ultrasound was used. Data about age of development of GM, anthropometric (height, weight) characteristics, degree of puberty according to Tanner stages as well as hormonal values [testosterone (T), luteinizing hormone ( $\mathrm{LH})$, follicle-stimulating hormone (FSH), estradiol (E2), thyroid-stimulating hormone (TSH), and prolactin (Prl)] were collected retrospectively. To evaluate the psychological impact of GM a questionnaire was answered.The hormonal parameters were measured by means of a chemiluminescent immunoassay "(Siemens, Immulite 2000 USA)". Descriptive statistics and frequency analysis were used where appropriate. Comparisons between groups were made through Independent-Samples t-test. $p$ values of $\leq 0.05$ were accepted as statistically significant. Data were analyzed by SPSS (Statistical Package for Social Sciences) version 13.0.

\section{Results}

For the aforementioned period from a total of 2039 boys and adolescents referred to Department of Endocrinology $157(7.7 \%)$ were diagnosed with GM. From them $76.43 \%$ were diagnosed also with obesity, $3.18 \%$ were overweight $(\mathrm{n}=125)$ and $20.39 \%(\mathrm{n}=32)$ with normal weight. Twelve $(7.64 \%)$ were below the age of nine without pubertal development so considered as prepubertal. Of the studies performed, the most common cause was elevated $E_{2}(n=6)$, five - obese. From the group with elevated $E_{2}$ one boy had also elevated prolactin due to therapy with Risperidone and Sodium valproate and in one advanced bone maturation (by 2.5 years) was registered.

Primary or secondary testicular damage and development of hypergonadotropic hypogonadism were diagnosed in $8(5.09 \%)$ of the boys. This group includes 4 boys with Klinefelter syndrome (46, XXY), one with a disorder of sexual differentiation (karyotype with two lines 46, XX (25)/47, XXY (5), one boy-Testicular regression syndrome, one - acquired testicular damage due to Acute lymphoblastic leukemia and one patient has congenital unilateral cryptorchidism and surgically removed at 4 years of age only testicle. 
Table 1. Causes and age of development of gynaecomastia in different patients and hormonal characteristics in the investigated group. Data are presented as median (n), min-max. All groups include boys and adolescents at different stages of pubertal development. Hormonal values of every patient were compared with reference values for the specific pubertal stage or age

\begin{tabular}{|c|c|c|c|c|c|c|c|c|c|}
\hline $\begin{array}{l}\text { Causes } \\
\text { of gynaecomastia }\end{array}$ & $\mathbf{N}$ & $\%$ & $\begin{array}{c}\text { Age of } \\
\text { development }\end{array}$ & $\begin{array}{c}\text { Time before } \\
1^{\text {st }} \text { medical } \\
\text { consultation } \\
\text { [years] }\end{array}$ & $\begin{array}{l}\text { Testosterone } \\
{[\mathrm{nmol} / \mathrm{L}]}\end{array}$ & $\begin{array}{c}\text { Oestradiol } \\
\text { [pmol/L] }\end{array}$ & $\begin{array}{c}\text { FSH } \\
{[\mathrm{mlU} / \mathrm{mL}]}\end{array}$ & $\begin{array}{c}\text { LH } \\
{[\mathrm{mIU} / \mathrm{mL}]}\end{array}$ & $\begin{array}{c}\text { Prolactin } \\
{[\mathrm{mlU} / \mathrm{L}]}\end{array}$ \\
\hline $\begin{array}{l}\text { Prepubertal } \\
\text { development }\end{array}$ & 12 & 7.64 & $\begin{array}{l}7.53(12) \\
0.69-9.0\end{array}$ & $\begin{array}{c}1.91 \\
(0.12-5.33)\end{array}$ & $\begin{array}{l}0.693(10), \\
0.37-1.77\end{array}$ & $\begin{array}{c}96.2(10) \\
41-189\end{array}$ & $\begin{array}{c}0.91(9) \\
0.149-3.31\end{array}$ & $\begin{array}{c}0.30(9) \\
0.104-0.67\end{array}$ & $\begin{array}{c}181.75(9) \\
110-267\end{array}$ \\
\hline $\begin{array}{l}\text { Hypergonadotropic } \\
\text { hypogonadism }\end{array}$ & 8 & 5.09 & $\begin{array}{l}13.57(8), \\
10-16.25\end{array}$ & $\begin{array}{c}1.65 \\
(0.25-3.83)\end{array}$ & $\begin{array}{l}1.21(8), \\
0.3-7.04\end{array}$ & $\begin{array}{c}139.86(8) \\
18.35-164.87\end{array}$ & $\begin{array}{c}49.8(8), \\
1.8-59.15\end{array}$ & $\begin{array}{c}20.82(8) \\
1.88-29.96\end{array}$ & $\begin{array}{c}222.5(8), \\
109.8-441\end{array}$ \\
\hline $\begin{array}{l}\text { Hypogonadotropic } \\
\text { hypogonadism }\end{array}$ & 9 & 5.73 & $\begin{array}{c}12.77(9), \\
10.5-14 \\
\end{array}$ & $\begin{array}{c}2.94 \\
(1.42-4.83)\end{array}$ & $\begin{array}{l}0.693(9), \\
0.15-5.51\end{array}$ & $\begin{array}{c}119(9) \\
62.5-164 \\
\end{array}$ & $\begin{array}{c}1.18(9) \\
0.114-8.96\end{array}$ & $\begin{array}{l}0.573(9), \\
0.1-3.91\end{array}$ & $\begin{array}{c}267.8(9), \\
135-413 \\
\end{array}$ \\
\hline Hyperprolactinaemia & 18 & 11.46 & $\begin{array}{l}12.06(18), \\
9.33-15.25\end{array}$ & $\begin{array}{c}1.46 \\
(0.25-3.92)\end{array}$ & $\begin{array}{c}7.44(17) \\
0.34-15.6\end{array}$ & $\begin{array}{l}97.6(18), \\
36.7-211\end{array}$ & $\begin{array}{c}3.27(17) \\
1.37-6.77\end{array}$ & $\begin{array}{c}4.97(17) \\
0.605-7.45\end{array}$ & $\begin{array}{c}438.5(18), \\
354-755\end{array}$ \\
\hline $\begin{array}{l}\text { Pubertal } \\
\text { gynaecomastia }\end{array}$ & 110 & 70.08 & $\begin{array}{l}11.84(104), \\
9.33-16.92\end{array}$ & $1.66(0.04-5)$ & $\begin{array}{c}4.47(92) \\
0.693-28.9\end{array}$ & $\begin{array}{c}122(93) \\
73.4-470\end{array}$ & $\begin{array}{c}2.77(92) \\
0.121-15.7\end{array}$ & $\begin{array}{c}2.83(93) \\
0.1-13.4\end{array}$ & $\begin{array}{c}(93) \\
49-359\end{array}$ \\
\hline
\end{tabular}

The third group are those with hypogonadotropic hypogonadism - a total of 9 boys $(5.73 \%)$. In this group two boys $(1.27 \%)$ were diagnosed with Kallman syndrome, and one boy with a normal sense of smell. Another 5 boys $(3,18 \%)$ were with Constitutional delay in growth and pubertal development (CDGPD) and low $\mathrm{T}$ with elevated $\mathrm{E}_{2}$ in 4 of them. One boy was diagnosed with Hypopituitarisym.

Elevated Prl levels were found in -20 boys ( 1 boy in the prepubertal group and 1 with CDGPD, increased $\mathrm{E}_{2}$ and $\left.\operatorname{Prl}\right)$. In this group, two more boys (1.28\%) were treated with drugs leading to hyperprolactinemia (paliperidone, quetiapine, haloperidol). In one boy, elevated prolactin were found along with elevated TSH due to undiagnosed Hashimoto's thyroiditis. In 3 boys $(1.91 \%)$ hyperprolactinemia led to decreased levels of gonadotropic hormones and delayed puberty. In the remaining 14 boys, prolactin was elevated at varying degrees but without abnormalities in gonadotropic hormones or adenohypophyseal hyperplasia (in 6 of them combined with increased E2).

In 110 boys (70.06\%), no other cause of GM was identified, so considered physiologic pubertal. No boys with GM due to tumors, hyperthyroidism, chronic liver failure and chronic kidney disease were identified (Tab. 1).

A statistically significant difference was found between the mean age of development of physiologic pubertal GM and those due to hypergonadotropic $(\mathrm{p}=0.006)$ and hypogonadotropic $(\mathrm{p}=0.028)$ hypogonadism. The onset of pubertal GM in boys with a normal weight was found 13.13 years, and in boys with overweight and obesity 11.69 years $(p<0.001)$.

Breast development is a sign typical for females and when GM occurs in adolescents this happens at an age associated with the development of identity and establishment of self-esteem. The appearance of breast tissue may lead to anxiety, a sense of difference from peers, as well as limit social contacts and participation in sport, especially group sports. That is why patients were asked several questions. Eighty four patients $(53.5 \%)$ confessed a psychological burden of GM (feeling of shame, embarrassment, reduced well-being, anxiety), $12.1 \%$ consulted because of its development, in 8.2\% GM led to cessation of sports and $2.5 \%$ changed their clothes.

\section{Conclusions}

In our study nearly a quarter of pubertal cases are due to pathologic conditions and those are often diagnosed more than 18 months after the appearance of breast. So although greater number of pubertal GM is physiologic it may be reasonable adolescents to be evaluated within the first 6 months of breast development so not to omit pathologic ones and delay the diagnosis. Additionally we found that GM has a complex influence on psychologic state of boys and adolescents. Perhaps an early establishment of the patient's condition may have a positive impact on his psychological state, behavior and habits especially in obese boys with pubertal GM.

\section{References}

1. Deepinder F, Braunstein GD. Gynecomastia: incidence, causes and treatment. Expert Rev Endocrinol Metab. 2011; 6(5): 723-730, doi: 10.1586/eem.11.57, indexed in Pubmed: 30780874.

2. Carlson HE. Approach to the patient with gynecomastia. J Clin Endocrinol Metab. 2011; 96(1): 15-21, doi: 10.1210/jcem.96.9.zeg15a, indexed in Pubmed: 21209041.

3. Rahmani S, Turton P, Shaaban A, et al. Overview of gynecomastia in the modern era and the Leeds Gynaecomastia Investigation algorithm. Breast J. 2011; 17(3): 246-255, doi: 10.1111/j.1524-4741.2011.01080.x, indexed in Pubmed: 21477170.

4. Rivera NF, Eisenstein E, Cardoso CB. [The relation between pubertal gynecomastia and body mass index in a sample of adolescents attended at the Outpatient Health Unit of a University Hospital]. Arq Bras Endocrinol Metabol. 2009; 53(4): 435-439, doi: 10.1590/s0004-27302009000400008, indexed in Pubmed: 19649381. 